\title{
INFLUENCE OF TIME OF HATCHING ON SEXUAL MATURITY OF PULLETS IN PUERTO RICO
}

\author{
A. GONZĀLEZ-CHAPEL AND M. ROJAS DAPORTA ${ }^{1}$
}

\section{INTRODUCTION}

The problem of the adaptability of livestock and poultry breeds to tropical climates has been of considerable interest to many workers in the last few years. A re-examination, under tropical conditions, of fundamental facts already ascertained in temperate climates, appears to be necessary for a better understanding of the problem.

Sexual maturity is considered as one of the three most important heritable factors determining egg production. By sexual maturity is meant the number of days between the date a pullet is hatched and the date she lays her first egg. Date of hatch is probably the most important nongenetic factor affecting sexual maturity. Rice, Hall, and Marble (5), concluded:

The distribution of eggs and also the total annual production in the first laying year of an individual or a flock is influenced greatly by the time of the year that the individual or flock is hatched. The effect of early or late hatching is undoubtedly greater in the first laying year than it is in the later laying years. The influence of time of hatching no doubt is due primarily to the environmental conditions as affecting rearing and subsequent produstion. Frequently the unfavorable conditions may be overcome so that the time of hatching becomes an unimportant factor. In those sections of the country where the widest extremes of seasons occur, the influence of time of hatching is greatest, and on the other hand in those regions having the most uniform and favorable climatic conditions there is much less difference.

Knowledge of the kind and extent of the influence of time of hatching on the sexual maturity of pullets in Puerto Rico is necessary for the proper evaluation of the environmental factors affecting egg production in the tropics.

\section{REVIEW OF LITERATURE}

Ample research has been done in the United States on the subjects of time of hatching, date of first egg, sexual maturity, and egg production.

The correlation between sexual maturity and egg production has been very definitely demonstrated by many workers. According to Rice, Hall, and Marble (5), three different experiment stations, Massachusetts, Missouri, and Cornell, reporting on the relationship between sexual maturity and egg production based on the records of 2,846 birds, covering a period of ten years, presented very significant correlations between sexual maturity

${ }^{1}$ Associate Animal Husbandman and Assistant Animal Husbandman, respectively, Agricultural Experiment Station, University of Puerto Rico, Rio Piedras, P.R. 
and annual egg production. This means that under normal conditions the less the number of days to date of first egg the greater will be the number of eggs laid in one year. Birds maturing extremely early are less desirable because of the small body size and egg size.

Jull (2), details a number of investigators which have shown that the time of the year that a pullet commences laying is important from the standpoint of the total number and value of eggs laid during the first laying year.

Rice, Hall, and Marble (5), reported the following data from the Oklahoma A. and M. College on the relationship of time of hatching and sexual maturity:

$\begin{array}{lc}\text { Season hatched } & \text { Days to first egg } \\ \text { Early Winter } & 156.4 \\ \text { Late Winter } & 185.3 \\ \text { Early Spring } & 236.3 \\ \text { Late Spring } & 233.7 \\ \text { Early Summer } & 229.3 \\ \text { Late Summer } & 214.3 \\ \text { Early Fall } & 195.5 \\ \text { Late Fall } & 178.6\end{array}$

Jull (2), states that in order to be able to compare the egg records of dams and daughters or of sisters, they should be hatched at relatively the same time each year because time of hatch influences egg production. In Puerto Rico, González Chapel (1), concluded that allowance for the date of hatching, as a factor influencing egg production, sexual maturity, egg weight, and body weight at the end of the first month of age, should be made when planning comparisons between breeds.

Knox, (4), in Iowa, studied the relationship between date of hatch and annual egg production in White Leghorns which were hatched from February 8 to June 8 , inclusive and found that the best egg production was obtained from the birds which were hatched from the latter part of March to the latter part of May.

Knox (3), in a study of the influence of the date of first egg upon maturity and production, concluded that the time that the first egg was laid had a curvilinear association with winter egg production; that there was a slight curvilinear association between the date of first egg and the rate of spring egg production; and that the records showed a curvilinear association

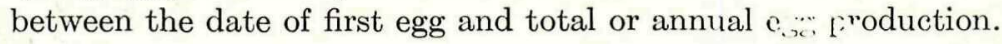

\section{PROCEDURE}

This study includes data collected during four years, from 1946 to 1949 . Sexual maturity was recorded on a total of 1372 pullets of the New Hampshire, White Leghorn, Native, and crossbreds. 
The New Hampshires and White Leghorns came from stock originally imported from the United States in 1940. The crossbreds included lines developed from original crosses of New Hampshires $x$ Natives; re-Line 1, Line 5; and White Leghorn x Natives; re-Line 3, Line 6.

In 1946 the data included 307 birds which were distributed as follows: New Hampshire, 144; White Leghorn, 103; and Natives, 60. In 1947 information was collected on 478 birds as follows: New Hampshire, 188; White Leghorn, 78; Natives, 49; Line 6, 104; Line 3, 25; and Line. 1, 34. The data in 1948 came from 266 birds of the following breeds: New Hampshire, 139; Line 3, 33; Line 1, 48; and Line 5, 46. In 1949 the data included 321 birds as follows: New Hampshire, 212; Line 3, 61; and Line 1, 48.

The hatching season started on January 16 on each of the four years. The first hatch came on February 6 and subsequent hatches came at weekly intervals after that date. In 1946, 1948 and 1949 the hatches extended from February 6 to June 5. In 1947 they extended from February 6 to April 2 with the exception of Line 1 chicks which were hatched up to May 21.

The eggs from all breeds and crossbreds were hatched in the same incubator; the same feed was given all the birds; they were reared in the same brooder houses and the same men took care of all the breeds.

Sexual maturity was measured as the age in days of the bird at first egg.

Previous work by González Chapel (1), had shown significant differences in sexual maturity between the purebreds and the Natives. For that reason all data was treated separately by breeds and by years.

The statistical analyses of the data reported here was mainly concerned with the evaluation of the effect of time of hatching on the sexual maturity of the pullets and the description of the regression of sexual maturity on time of hatching.

\section{RESULTS}

A preliminary analysis of the data showed that time of hatching had a negligible effect on the sexual maturity of 4 out of the 16 groups of birds considered. This was true in 1947, with the 49 Native pullets and the 104 Line 6 pullets; in 1948 with the 46 Line 5 pullets and in 1949 with the 48 Line 1 pullets. These four groups were, accordingly, not further considered in the analysis.

The differences in sexual maturity of the birds due to time of hatching were statistically significant in the other 12 groups.

Table 1 shows the mean sexual maturity of all breeds in each year studied.

In table 2 the mean sexual maturity by hatches during 1946 is presented.

Figures 1, 2, and 3 shows the regression of sexual maturity on time of 
hatching for the New Hampshires, White Leghorns and Natives, respectively, during 1946.

TABLE 1.-Mean sexual maturity in days by breeds and by years

\begin{tabular}{|c|c|c|c|c|}
\hline \multirow{2}{*}{ Breed } & \multicolumn{4}{|c|}{ Year } \\
\hline & 1946 & $19+7$ & 1948 & 1949 \\
\hline New Hampshire. . . . . . . . . . . . . & 225.6 & 220.5 & 234.6 & 234.7 \\
\hline White Leghorn . . . . . . . . . . . . . . & 200.1 & 196.0 & - & - \\
\hline Natives . . . . . . . . . . . . . . . & 231.4 & 185.8 & - & - \\
\hline Line $1 \ldots \ldots \ldots \ldots \ldots \ldots$ & - & 218.6 & 235.4 & 235.4 \\
\hline Line $3 \ldots \ldots \ldots \ldots \ldots \ldots$ & - & 183.9 & 246.6 & 244.8 \\
\hline Line $5 \ldots \ldots \ldots \ldots \ldots \ldots$ & - & - & 241.4 & - \\
\hline Line $6 \ldots \ldots \ldots \ldots \ldots \ldots \ldots \ldots \ldots \ldots$ & - & 216.6 & - & - \\
\hline
\end{tabular}

TABLE 2.-Mean sexual maturity in days by hatches in 1946

\begin{tabular}{|c|c|c|c|}
\hline \multirow{2}{*}{ Time of Hatch } & \multicolumn{3}{|c|}{ Breeds } \\
\hline & New Hampshires & White Leghorns & Natives \\
\hline February $6 \ldots \ldots \ldots \ldots \ldots \ldots$ & - & - & - \\
\hline February $13 \ldots \ldots \ldots \ldots \ldots$ & 186.3 & 175.9 & 179.0 \\
\hline February $20 \ldots \ldots \ldots \ldots \ldots \ldots$ & 184.5 & 171.5 & 185.5 \\
\hline February $27 \ldots \ldots \ldots \ldots \ldots \ldots$ & - & - & - \\
\hline March $6 \ldots \ldots \ldots \ldots \ldots \ldots \ldots$ & 201.0 & 205.4 & 一 \\
\hline March $13 \ldots \ldots \ldots \ldots \ldots \ldots$ & 211.8 & 216.7 & 212.3 \\
\hline $\operatorname{March} 20 \ldots \ldots \ldots \ldots \ldots \ldots$ & 203.2 & 197.7 & 288.5 \\
\hline March $27 \ldots \ldots \ldots \ldots \ldots \ldots \ldots$ & 190.3 & 191.2 & 287.0 \\
\hline April $3 \ldots \ldots \ldots \ldots \ldots \ldots$ & 215.8 & 210.3 & 249.2 \\
\hline April $10 \ldots \ldots \ldots \ldots \ldots \ldots \ldots$ & 232.0 & 188.9 & 242.3 \\
\hline April $17 \ldots \ldots \ldots \ldots \ldots \ldots$ & 237.4 & 185.8 & 240.5 \\
\hline April $24 \ldots \ldots \ldots \ldots \ldots \ldots$ & 243.1 & 204.0 & 238.8 \\
\hline May $1 \ldots \ldots \ldots \ldots \ldots \ldots$ & - & - & - \\
\hline May $8 \ldots \ldots \ldots \ldots \ldots$ & 263.7 & 194.7 & 249.7 \\
\hline May $15 \ldots \ldots \ldots \ldots \ldots \ldots \ldots$ & 244.3 & 224.5 & 228.3 \\
\hline May $22 \ldots \ldots \ldots \ldots \ldots \ldots \ldots$ & 251.5 & 227.2 & 219.3 \\
\hline May $29 \ldots \ldots \ldots \ldots \ldots \ldots \ldots \ldots \ldots \ldots \ldots \ldots$ & 245.6 & 218.0 & 177.8 \\
\hline June $5 \ldots$. & 263.0 & 209.8 & . $\quad 187.5$ \\
\hline
\end{tabular}

In the graph, each dot represents one pullet.

The three breeds were differently affected by the time of hatching. From February 6 to March 27 the regression was similar for the three breeds; 


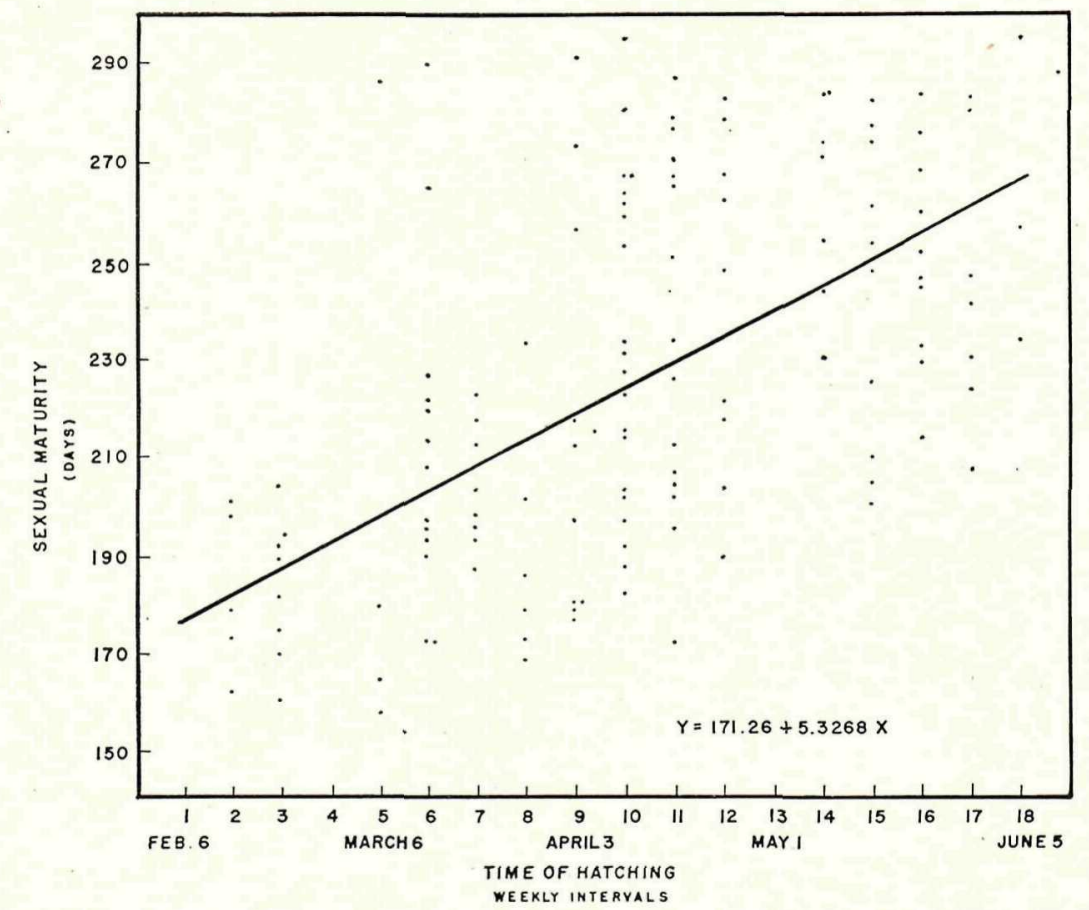

FIG. 1.-Influence of time of hatching on sexual maturity (New Hampshires1946)

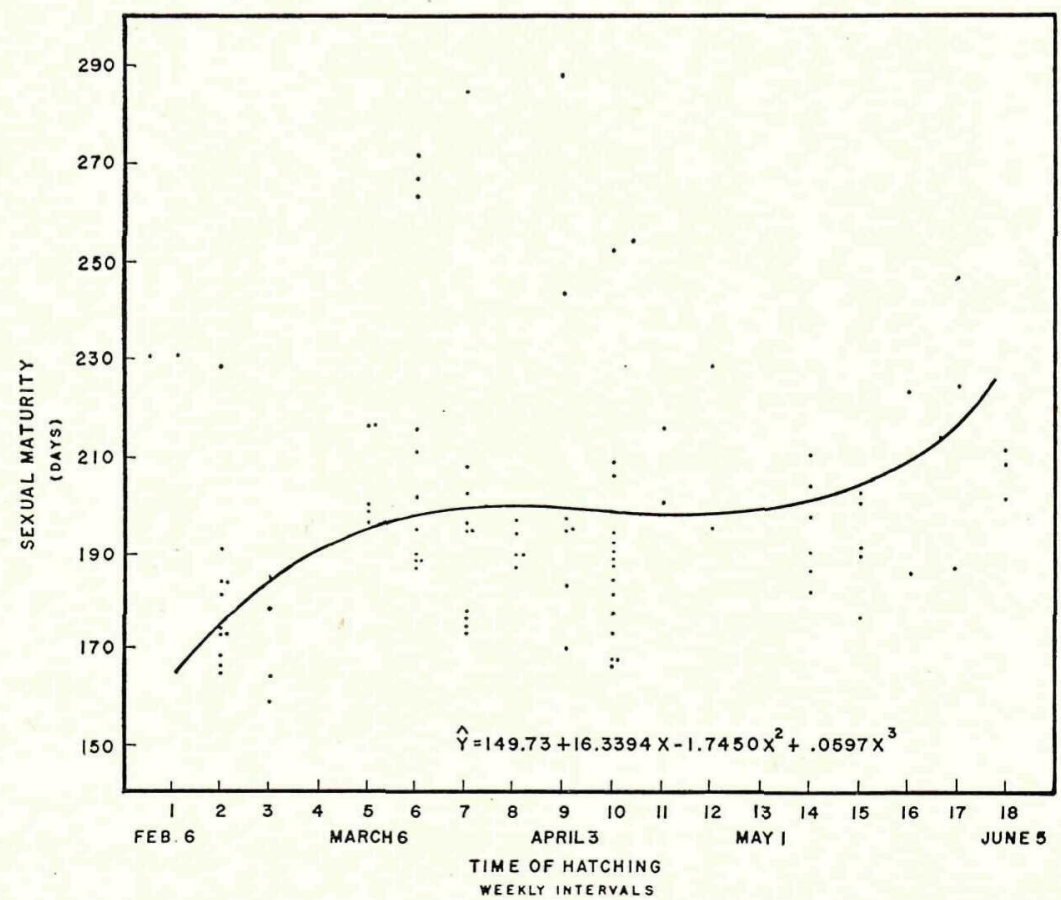

FIG. 2---Influence of time of hatching on sexual maturity (White Leghorns1946) 


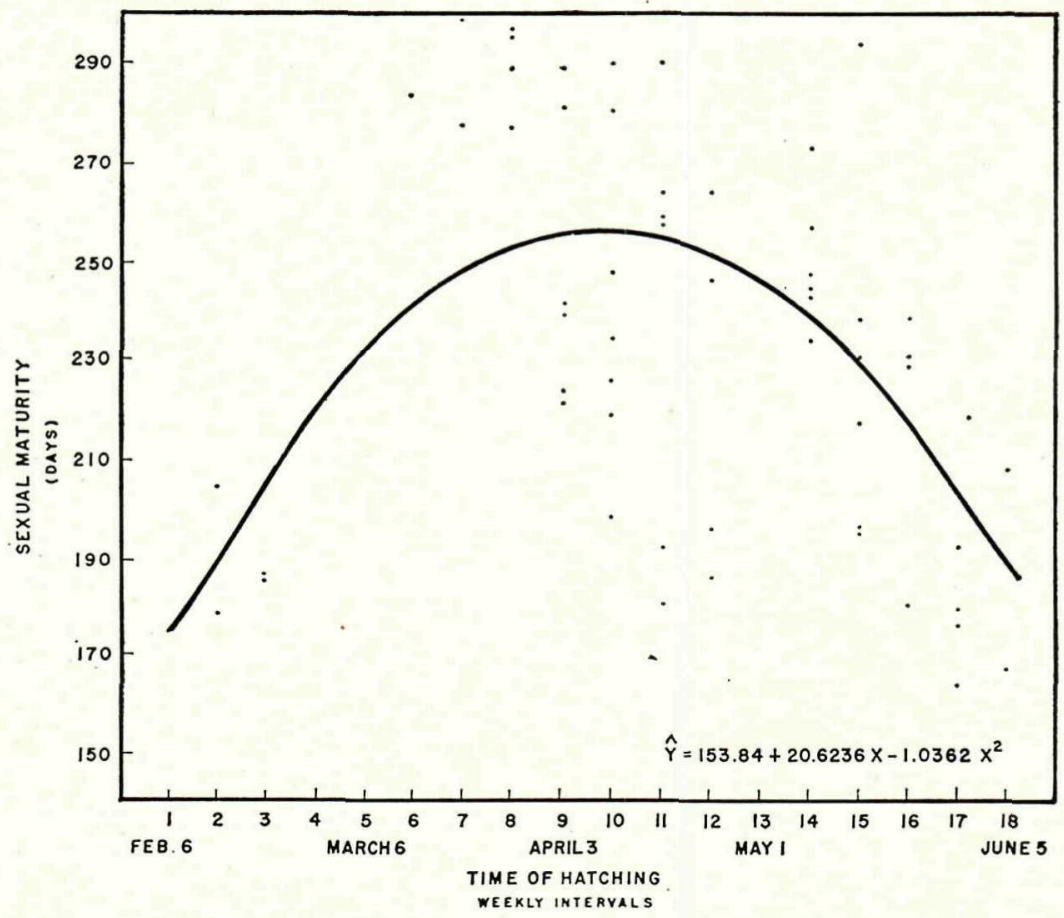

FIG. 3.-Influence of time of hatching on sexual maturity (Natives-1946)

TABLE 3.-Mean sexual maturity in days by hatches in 1947

\begin{tabular}{|c|c|c|c|c|}
\hline \multirow{2}{*}{ Time of Hatch } & \multicolumn{4}{|c|}{ Breeds } \\
\hline & $\begin{array}{l}\text { New } \\
\text { Hampshires }\end{array}$ & $\begin{array}{c}\text { White } \\
\text { Leghorns }\end{array}$ & Line 3 & Line 1 \\
\hline February $6 \ldots \ldots \ldots \ldots \ldots \ldots$ & 205.0 & 176.0 & - & - \\
\hline February $13 \ldots \ldots \ldots \ldots \ldots \ldots$ & 203.3 & 188.2 & 184.0 & 175.0 \\
\hline February $20 \ldots \ldots \ldots \ldots \ldots \ldots$ & 221.2 & 196.4 & 177.0 & - \\
\hline February $27 \ldots \ldots \ldots \ldots \ldots$ & 222.3 & 195.6 & 181.3 & 173.7 \\
\hline March $6 \ldots \ldots \ldots \ldots$ & 202.7 & 189.4 & 161.0 & 202.5 \\
\hline March $13 \ldots \ldots \ldots \ldots \ldots$ & 218.9 & 183.6 & 180.3 & - \\
\hline $\operatorname{March} 20 \ldots \ldots \ldots \ldots \ldots \ldots \ldots \ldots$ & 216.2 & 188.6 & 167.0 & 184.7 \\
\hline March $27 \ldots \ldots \ldots \ldots \ldots \ldots \ldots$ & 237.4 & 201.0 & - & - \\
\hline April $3 \ldots . .$. & 228.6 & 223.3 & - & 222.0 \\
\hline April $10 \ldots \ldots \ldots \ldots$ & - & - & 217.6 & 242.0 \\
\hline April $17 \ldots \ldots \ldots \ldots \ldots \ldots \ldots$ & - & - & - & 224.0 \\
\hline April $24 \ldots \ldots \ldots \ldots \ldots \ldots \ldots$ & - & - & - & 252.2 \\
\hline May $1 \ldots \ldots \ldots \ldots \ldots \ldots \ldots \ldots \ldots \ldots \ldots \ldots \ldots$ & - & - & - & 233.3 \\
\hline May $8 \ldots \ldots \ldots \ldots \ldots \ldots \ldots \ldots$ & - & - & - & - \\
\hline May $15 \ldots \ldots \ldots \ldots \ldots \ldots \ldots \ldots \ldots \ldots$ & - & - & - & 214.8 \\
\hline May $22 \ldots \ldots \ldots \ldots \ldots \ldots \ldots \ldots \ldots \ldots \ldots \ldots \ldots \ldots \ldots \ldots$ & - & - & - & 219.5 \\
\hline May $29 \ldots \ldots \ldots \ldots \ldots \ldots \ldots \ldots \ldots \ldots \ldots$ & - & - & - & - \\
\hline June $5 \ldots \ldots \ldots$. & - & - & - & - \\
\hline
\end{tabular}




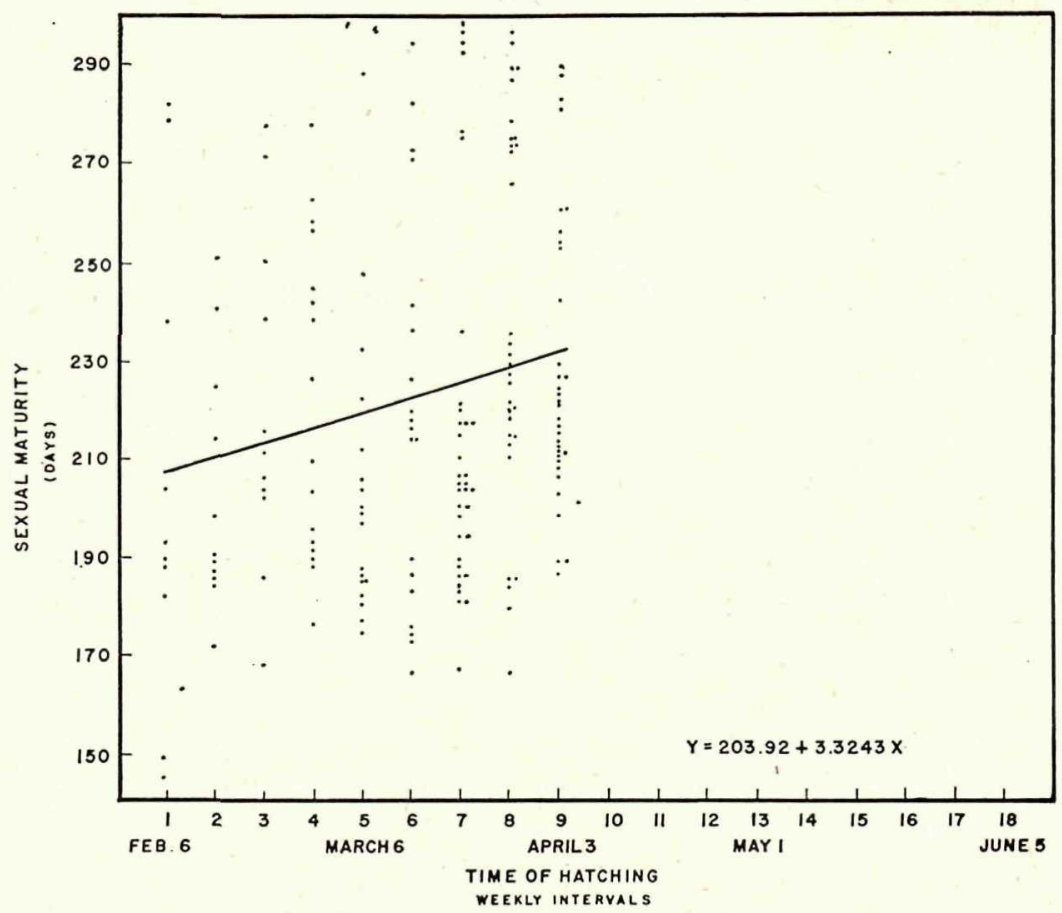

FIG. 4.-Influence of time of hatching on sexual maturity (New Hampshires1947)

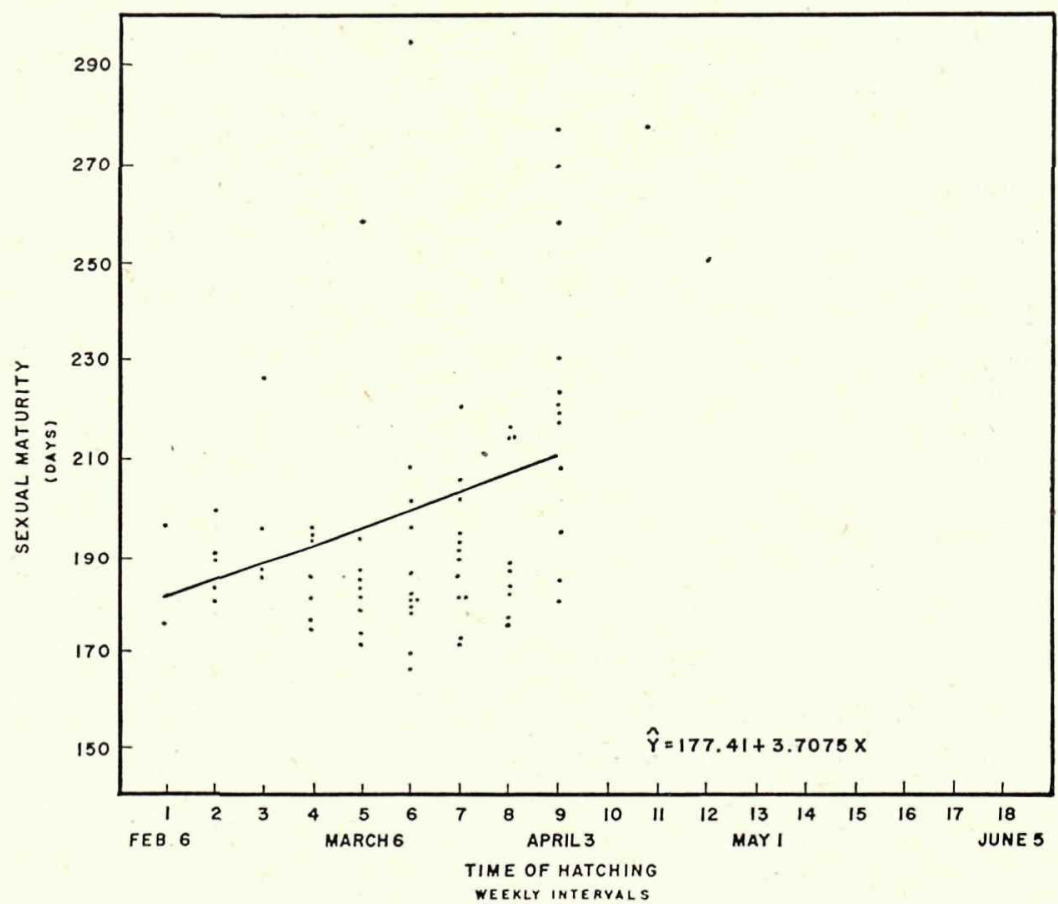

FIG. 5.-Influence of time of hatching on sexual maturity (White Leghorns1947) 


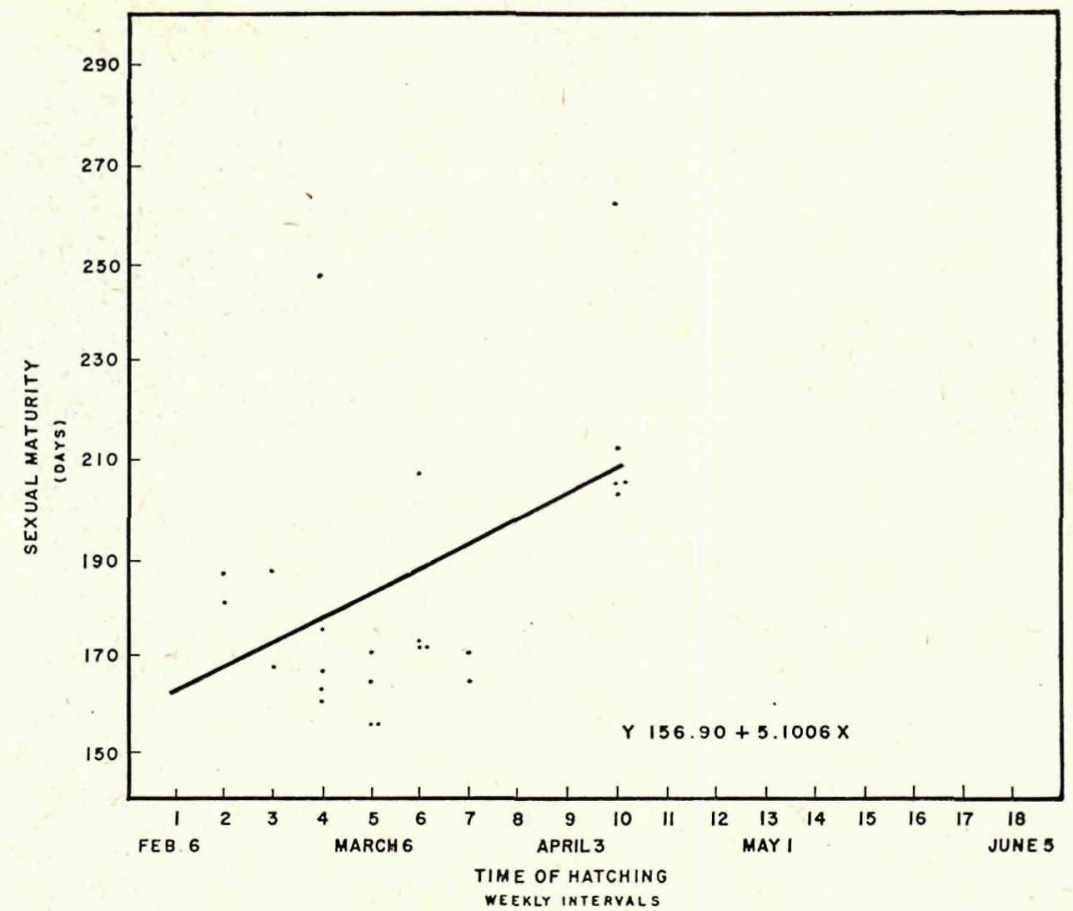

FIG. 6.-Influence of time of hatching on sexual maturity (Line 3-1947 (W.L. $x$ Nat.))

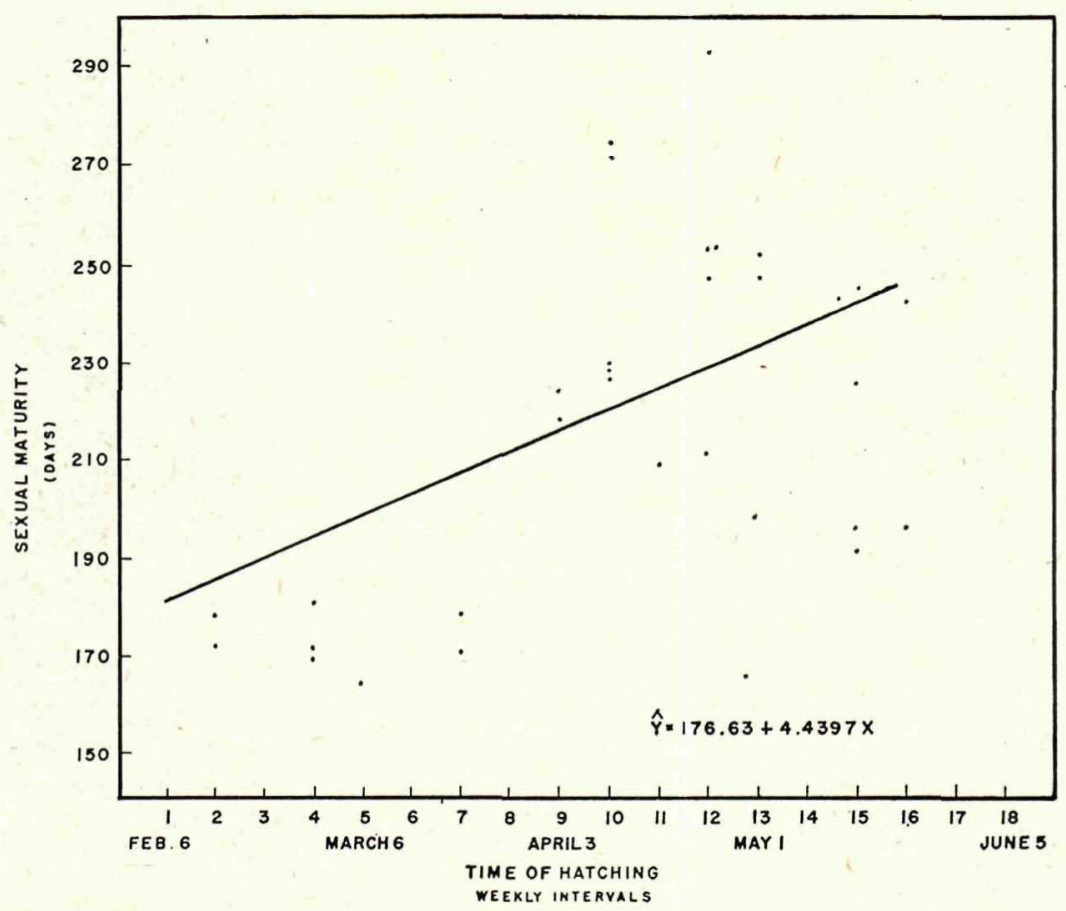

FIG, 7.-Influence of time of hatching on sexual maturity (Line 1-1947 (N.H. x Nat.)) 
the pullets hatched in February being earlier maturing than those hatched in March. The New Hampshire pullets hatched in March were earlier maturing than those hatched in April; the pullets hatched in April were earlier maturing than those hatched in May and June. The White Leghorn pullets hatched during April were similar in maturity to those hatched at the end of March but after April 23 those hatched earlier matured earlier. On the other hand, the Native pullets, after April 10, matured earlier when hatched later.

\begin{tabular}{|c|c|c|c|}
\hline \multirow{2}{*}{ Time of Hatch } & \multicolumn{3}{|c|}{ Breeds } \\
\hline & New Hampshire & Line 3 & Line 1 \\
\hline February $6 \ldots \ldots \ldots \ldots \ldots \ldots$ & 238.8 & - & - \\
\hline February $13 \ldots \ldots \ldots \ldots \ldots \ldots$ & 205.6 & - & 181.7 \\
\hline February $20 \ldots \ldots \ldots \ldots \ldots \ldots$ & 217.2 & 217.8 & 204.5 \\
\hline February $27 \ldots \ldots \ldots \ldots \ldots \ldots \ldots$ & 240.4 & 233.0 & 242.8 \\
\hline March $6 \ldots \ldots \ldots \ldots \ldots \ldots$ & 230.4 & - & 245.5 \\
\hline March $13 \ldots \ldots \ldots \ldots \ldots \ldots \ldots$ & 255.3 & 60.0 & 227.3 \\
\hline $\operatorname{March} 20 \ldots \ldots \ldots \ldots \ldots \ldots \ldots \ldots$ & 259.5 & 289.0 & 63.3 \\
\hline March $27 \ldots \ldots \ldots \ldots \ldots \ldots \ldots \ldots$ & 231.8 & 261.8 & - \\
\hline April $3 \ldots \ldots \ldots \ldots \ldots \ldots \ldots \ldots$ & 232.1 & 243.5 & 249.0 \\
\hline April $10 \ldots \ldots \ldots \ldots \ldots \ldots \ldots \ldots$ & 244.4 & 283.3 & 256.5 \\
\hline April $17 \ldots \ldots \ldots \ldots \ldots \ldots \ldots \ldots$ & 233.4 & - & 236.7 \\
\hline April $24 \ldots \ldots \ldots \ldots \ldots \ldots \ldots \ldots \ldots \ldots \ldots \ldots$ & 245.4 & - & 262.0 \\
\hline May $1 \ldots \ldots \ldots \ldots \ldots \ldots \ldots \ldots \ldots \ldots$ & 234.2 & 225.0 & - \\
\hline $\operatorname{May} 8 \ldots \ldots \ldots \ldots \ldots \ldots \ldots \ldots \ldots \ldots$ & 265.3 & 239.0 & 268.2 \\
\hline May $15 \ldots \ldots \ldots \ldots \ldots \ldots \ldots \ldots$ & 218.6 & 202.5 & 195.3 \\
\hline May $22 \ldots \ldots \ldots \ldots \ldots \ldots \ldots$ & 254.9 & 251.0 & 208.3 \\
\hline May $29 . \ldots \ldots \ldots \ldots \ldots \ldots \ldots \ldots \ldots$ & 200.6 & - & 198.5 \\
\hline June $5 \ldots \ldots \ldots \ldots \ldots \ldots \ldots \ldots$ & 241.0 & 221.5 & 269.5 \\
\hline
\end{tabular}

In table 3 the mean sexual maturity by hatches during 1947 is shown.

Figures 4, 5, 6 and 7 shows the regression of sexual maturity on time of hatching for the New Hampshires, White Leghorns, Line 3's and Line 1's, respectively, during 1947.

The regression was very similar for the four breeds during 1947. The pullets hatched in February were earlier maturing than those hatched in March, and those hatched in March were earlier maturing than those hatched in April. The regression in the Line 1 pullets, which were tested after April 10, was similar to that of the New Hampshires in 1946; the 


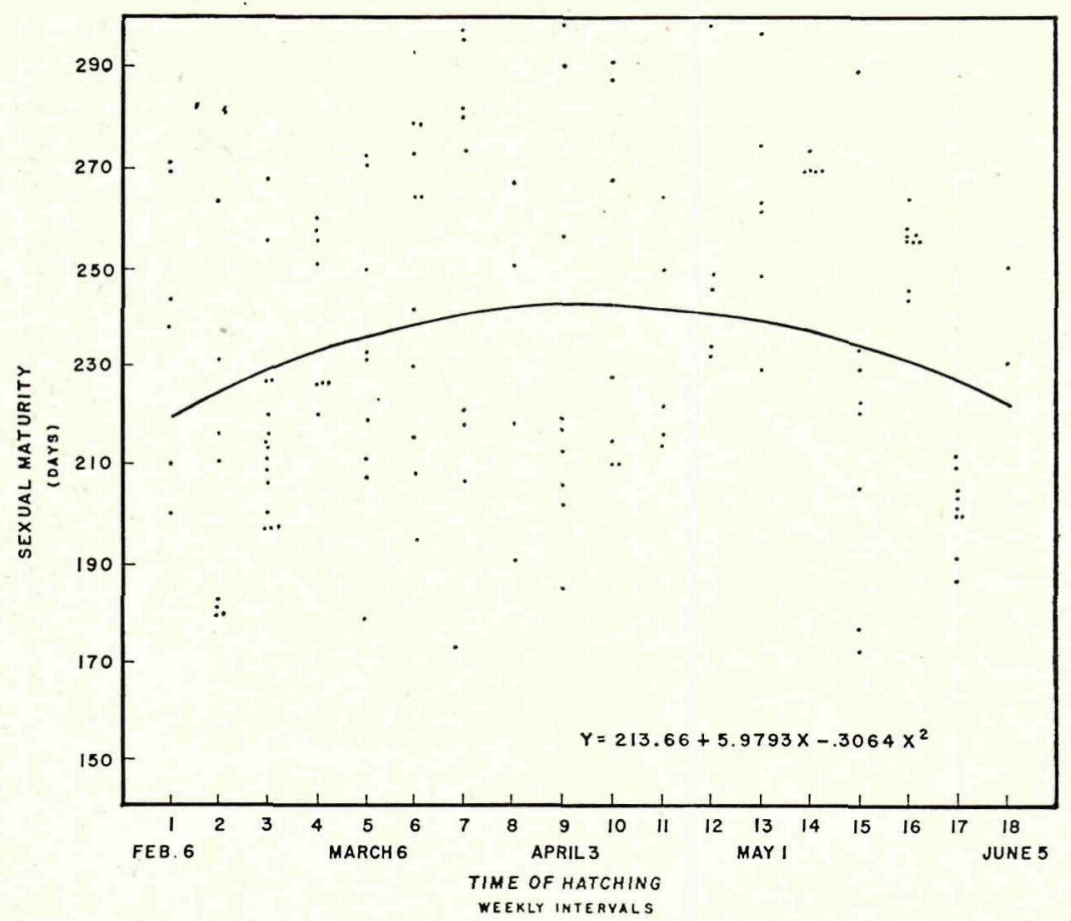

Fig. 8.-Influence of time of hatching on sexual maturity (New Hampshires1948)

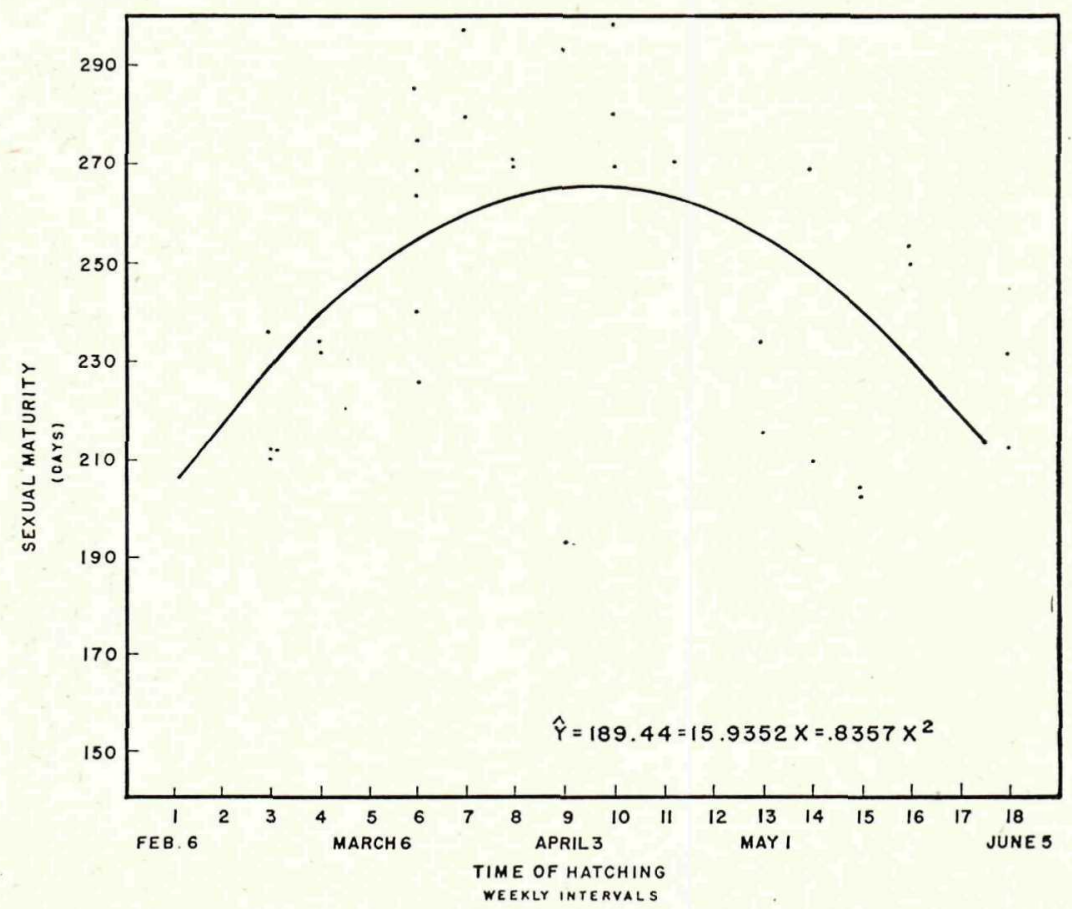

FIG. 9.-Influence of time of hatching on sexual maturity (Line 3-1948 (W.L. x Nat.)) 


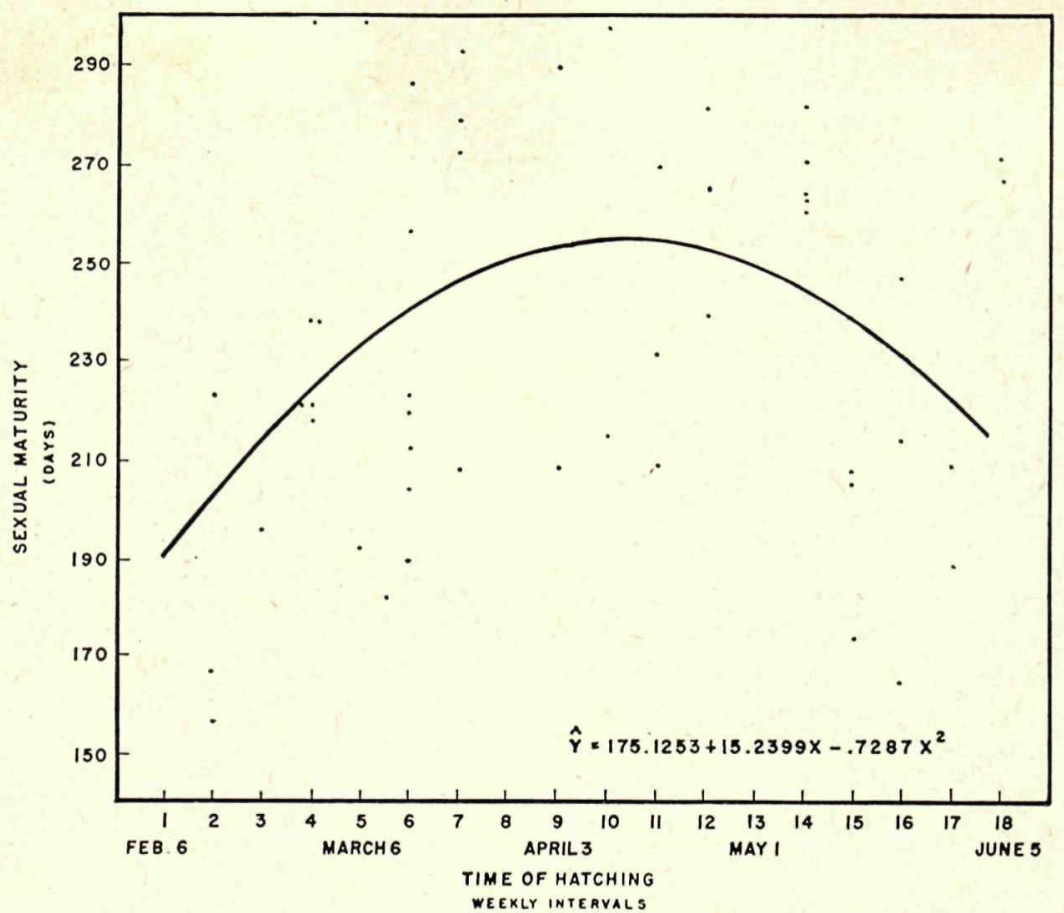

FIG. 10.-Influence of time of hatching on sexual maturity (Line 1-1948 (N.H. x Nat.))

TABLE 5.-Mean sexual maturity in days by hatches in 1949

\begin{tabular}{|c|c|c|}
\hline \multirow{2}{*}{ Time of Hatch } & \multicolumn{2}{|c|}{ Breeds } \\
\hline & New Hampshires & Line 3 \\
\hline February $6 \ldots \ldots \ldots \ldots \ldots \ldots \ldots \ldots \ldots \ldots \ldots \ldots \ldots \ldots$ & - & - \\
\hline February $13 \ldots \ldots \ldots \ldots \ldots \ldots \ldots \ldots \ldots$ & 195.3 & - \\
\hline February $20 \ldots \ldots \ldots \ldots \ldots \ldots \ldots \ldots \ldots$ & 181.3 & 261.5 \\
\hline February $27 \ldots \ldots \ldots \ldots \ldots \ldots \ldots \ldots \ldots \ldots \ldots \ldots \ldots$ & 207.4 & 211.0 \\
\hline March $6 \ldots . .$. & 234.4 & 201.7 \\
\hline 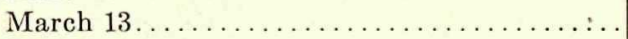 & 224.2 & 234.0 \\
\hline 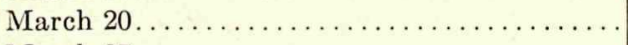 & 199.7 & 231.3 \\
\hline 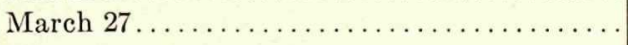 & 260.8 & 276.3 \\
\hline 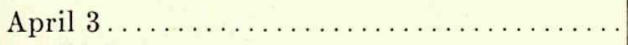 & 234.5 & 253.3 \\
\hline 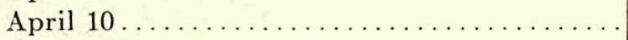 & 263.7 & 269.9 \\
\hline April $17 \ldots \ldots \ldots \ldots \ldots \ldots \ldots \ldots$ & 245.5 & - \\
\hline 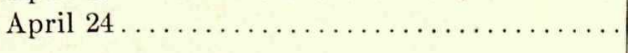 & 230.5 & 244.5 \\
\hline 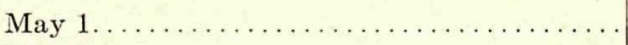 & 241.8 & 245.2 \\
\hline 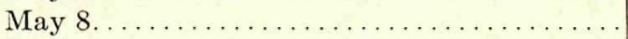 & 212.9 & 一 \\
\hline 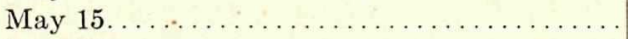 & 237.7 & 229.6 \\
\hline 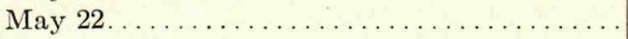 & 243.4 & 228.8 \\
\hline 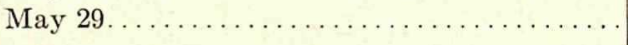 & - & - \\
\hline June $5 \ldots \ldots \ldots$ & - & - \\
\hline
\end{tabular}




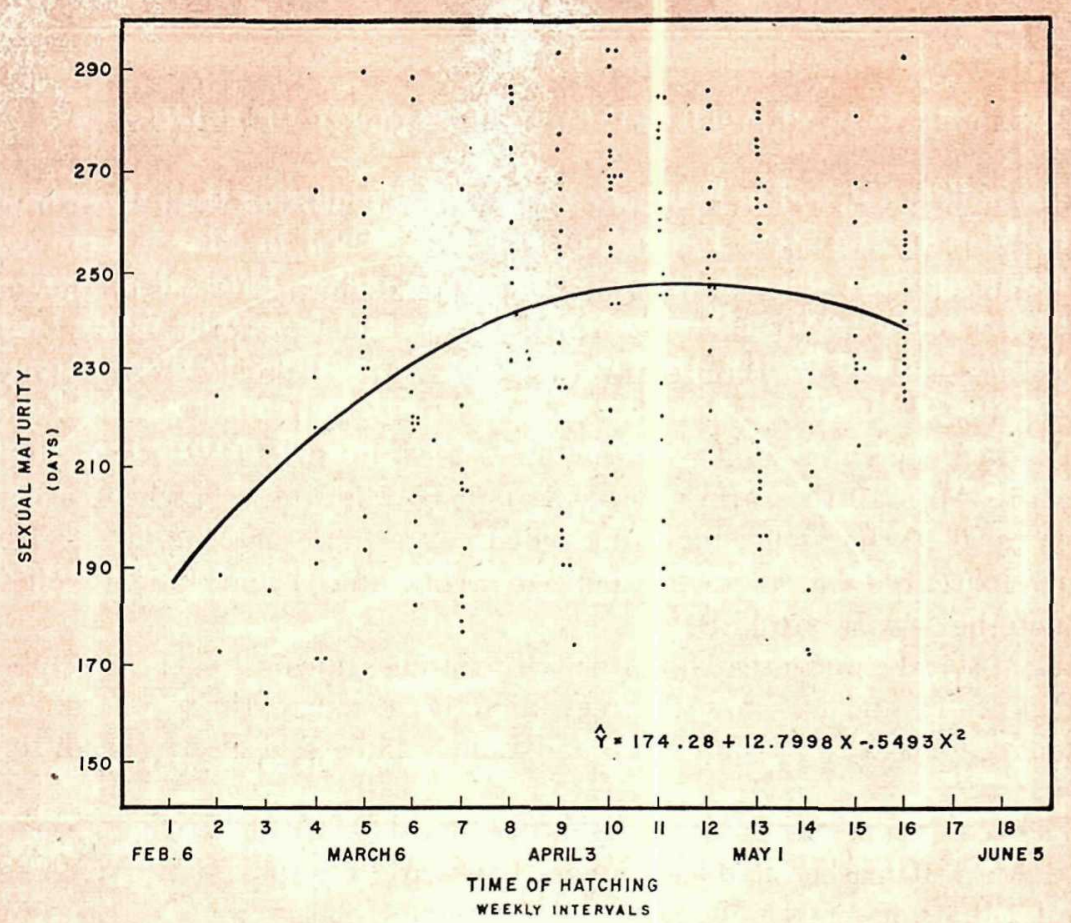

FIG. 11. -Influence of time of hatching on sexual maturity (New Hampshires1949)

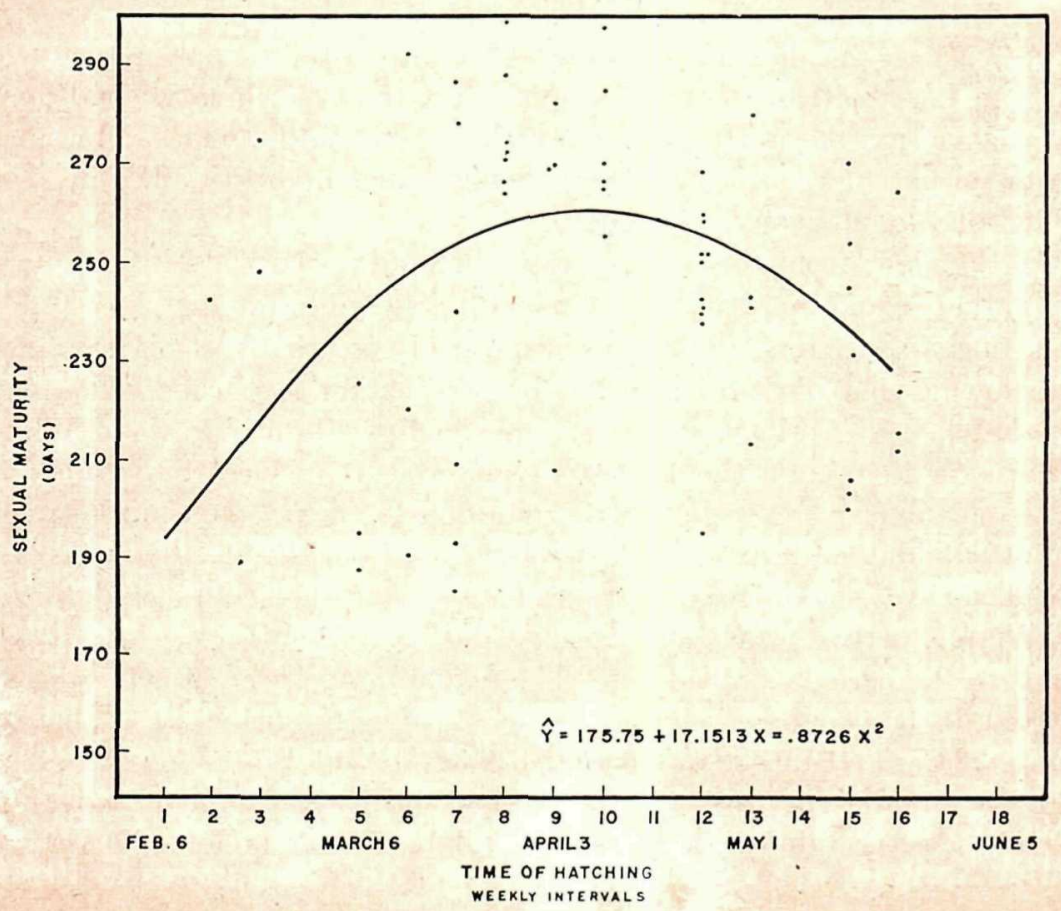

Fig. 12. -Influence of time of hatching on sexual maturity (Line 3-1949 (W.L. x Nat.))

111 
birds hatched earlier throughout the hatching season being earlier maturing than the birds hatched later.

In table 4 the mean sexual maturity by hatches during 1948 is presented.

Figures 8,9 and 10 show the regression of sexual maturity on time of hatching for the New Hampshire, Line 3 and Line 1 pullets, respectively, during 1948.

The regression was similar for the three breeds during 1948. From February 6 to April 10 the earlier maturing pullets were those hatched earlier; after April 10 the earlier maturing pullets were those hatched latest. The regression curve was more pronounced in the Line 3 and Line 1 pullets than in the New Hampshires.

In table 5 the mean sexual maturity by hatches during 1949 is presented.

Figures 11 and 12 show the regression of sexual maturity on time of hatching for the New Hampshire and Line 3 pullets, respectively, during 1949.

The regression was similar for the two breeds in 1949. From February 6 to April 10 earlier hatched pullets had earlier sexual maturity. After April 17 late hatched pullets had earlier sexual maturity. The regression curve was more pronounced in Line 3 birds than in New Hampshires.

\section{CONCLUSIONS}

Time of hatching has an important effect upon the sexual maturity of pullets in Puerto Rico. Regardless of the fact that the climatic conditions in the Island are relatively uniform, with no seasonal extremes, allowance for time of hatching, as a factor influencing sexual maturity and thus, egg production, should always be made.

It is apparent from the data studied that pullets hatched in February have earlier sexual maturity than pullets hatched in March.

The curvilinear trend was strong in most of the groups of birds considered showing that birds hatched in May had earlier sexual maturity than those hatched in April. Exceptions were the New Hampshires and White Leghorns in 1946, and, though less pronounced, the Line 1 birds in 1947.

This curvilinear trend somewhat conforms to the relationship between time of hatching and sexual maturity reported from the Oklahoma A. and M. College in Rice, Hall and Marble's book (5). In the Oklahoma data the late Winter, early Spring, late Spring, and early Summer periods corresponds to the periods studied here. The sexual maturity in late Winter, as reported in the Oklahoma study, was 185.3; in early Spring, 236.3; in late Spring, 233.7; and in early Summer, 229.3. The only difference found in the data reported in this study was that the early Summer pullets in Puerto Rico were almost as early as the late Winter pullets. The curvi- 
linearity of the regression was, in most groups, much more pronounced than that reported in the Oklahoma data.

No attempt can be made as yet to explain the cause of the influence of the time of hatching on the sexual maturity of the pullets in Puerto Rico. Further studies are necessary, relative to the environmental and/or physiological factors which may be contributing to the effect. Environmental factors, such as temperature, rainfall, humidity, length of day light and their effect on the rearing and subsequent production of the pullets, should be evaluated, and correlated with the time of hatching to seek a possible relationship. The curvilinear trend suggests that molting could be a possible explanation for the influence of time of hatching on the sexual maturity of the pullets, as reported here.

\section{SUMMARY}

This study included the sexual maturity of 1,372 pullets of different breeds and crossbreds hatched from February 6 to June 5 in 1946, 1947, 1948 and 1949.

Time of hatching was found to exert an important influence on the sexual maturity of pullets in Puerto Rico.

Pullets hatched in February had earlier sexual maturity than pullets hatched in March.

In most of the groups of birds studied, a curvilinear trend was apparent showing that birds hatched in May had earlier sexual maturity than those hatched in April.

A series of graphs showing the regression of sexual maturity on time of hatching, by breeds and by years, are presented. 